\title{
Influence at Work tied to Materiality in Danish Care Work'
}

\section{Peter Aske Svendsen²}

Research Assistant, National Research Centre for the Working Environment, Denmark

I Johan Simonsen Abildgaard

Senior Researcher, National Research Centre for the Working Environment, Denmark

\section{Lene Tanggaard}

Rector, Design School Kolding, Denmark

\section{Ida Elisabeth Huitfeldt Madsen}

Senior Researcher, National Research Centre for the Working Environment, Denmark

\section{Malene Friis Andersen}

Researcher, National Research Centre for the Working Environment, Denmark

\begin{abstract}
Influence at work is known to be an important factor for workers health. Researchers have called for studies on influence at work as a contextualized phenomenon. Based on individual interviews with managers and focus group interviews with employees in three care workplaces, the article shows how the materiality of the work setting ties employees' influence to perform tasks in both hindering and enabling ways. We show that a work environment where employees' influence is hindered produces negative experiences in the work environment, while an environment where employees' influence is enabled produces positive experiences. Additionally, we study how employees influence the material aspects of their workplace. We present a view of influence at work as constituted by materiality and social organization in sociomaterial assemblages. This study reintroduces materiality as a concern in psychosocial work environment research and contributes a sociomaterial view on influence at work and materiality.
\end{abstract}

\section{KEYWORDS}

Autonomy / care work / influence at work / job control / materiality / psychosocial work environment / sociomateriality / work organization

\section{Introduction}

nfluence, control, and autonomy are central concepts in psychosocial work environment research and have been so since the field's inception (Gardell 1977; Hackman \& Oldham 1976; Karasek 1979; Trist \& Bamforth 1951). The concepts are defined in

\footnotetext{
${ }^{1}$ You can find this text and its DOI at https://tidsskrift.dk/njwls/index.

${ }^{2}$ Corresponding author: Peter Aske Svendsen, National Research Centre for the Working Environment, Lersø Parkallé 1052100 Copenhagen, Denmark. e-mail: pea@nfa.dk.
} 
multiple ways, but all address the importance for employees to act with a degree of freedom and ability to impact work tasks and structures. Influence at work is an especially important part of contemporary psychosocial work environment research, and one that has received substantial attention in the Nordic countries (Hasle \& Sørensen 2013), and the interest in influence is reasonable. Research shows that influence at work is important for workers' engagement, innovation, and sense of meaning in their work (De Spiegelaere et al. 2016; Ravn 2008). Quantitative studies show that influence at work is one of the factors most clearly associated with beneficial outcomes for health (Karasek et al. 1981; Kivimäki et al. 2012; Theorell et al. 2015). Recently, researchers have called for more studies on influence at work (Amble 2013: 57; Bolin \& Olofsdotter 2019: 6-7; Hvid 2009), specifically on how influence unfolds in relation to contextual factors at workplaces (Rugulies et al. 2019: 20; Väänänen \& Toivanen 2018). This article addresses such calls for research employing qualitative methods to study how influence at work is tied to material aspects at workplaces. The present study presents three cases within care work, where employees highlight relations between their influence and the physical design at workplaces. We show how the physical design of workplaces enable or hinder employee's influence on how to perform tasks. Additionally, we show how employees seek to influence the physical design of workplaces with implications for wellbeing. We analyze this situation to argue that employee influence is tied to buildings and spatial arrangements in the work setting. We place our analysis within a sociomaterial framework, treating influence at work and workplace materiality as constitutive of sociomaterial assemblages (Orlikowski 2005, 2007) that emerge through practical engagement inherent in care work. A sociomaterial framework enables us to account for how the physical design enables or hinders employees' influence on how to perform tasks and, simultaneously, how employees influence the physical design of their workplaces. Materiality has historically been a key concern in work environment research, though the focus on materiality within psychosocial work environment research faded, as workers increasingly transitioned from blue-collar to white-collar work. As an illustration, the recent Danish Psychosocial Questionnaire includes just two questions that can reasonably encompass material aspects at the workplace (Clausen et al. 2019). When current psychosocial work environment research does focus on materiality at the workplace, it is often on the introduction of new technologies (Ajslev et al. 2019; Ertner 2019). While most workers are increasingly working in environments void of classic material risk factors such as smoke or harmful particles, they do still work in material settings containing material artefacts. This study demonstrates the relationship between materiality at the workplace and care workers' influence at work to reintroduce materiality as a concern in psychosocial work environment research. Findings are based on qualitative data from three focus group interviews with employees and three interviews with managers within care work and thematically analyzed (Boyatzis 1998). We pose the research question: What is the relationship between influence at work and materiality in the experience of care workers?

Our findings show how employees' experience of physical design of buildings and spatial arrangements can both enable and hinder employees' influence to perform tasks. The contribution of this study is to show how the physical design of the workplace affects employees' influence on how to perform tasks and simultaneously show how different groups of employees seek to influence the physical design of their workplace. We show how these dynamics have implications for employee wellbeing and psychosocial

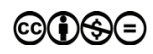


work environment. It is important to study a work environment term like influence at work as part of sociomaterial assemblages at the workplace to increase our understanding of the dynamic and interacting character of working conditions in care work today. We hope that this will stimulate further theoretical development of influence at work in work environment studies, and provide basis for increased thoughtful incorporation of psychosocial factors in physical design of workplaces.

\section{Theoretical background}

\section{Job control and tied influence: Influence at work in psychosocial work environment research}

Influence at work had the interest of work environment research pioneer Bertil Gardell (1977) and became an established corner stone of psychosocial work environment research through Karasek and Theorell's work on the Demand-Control Model (DCM) (Karasek 1979; Karasek \& Theorell 1990). This model conceptualizes influence as job control, consisting of skill discretion and task authority (Karasek 1979). Research based on the DCM has shown that low control at work combined with high demands is associated with serious health outcomes like cardiovascular disease (Karasek et al. 1981; Kivimäki et al. 2012; Theorell \& Karasek 1996), depression (Madsen et al. 2017; Theorell et al. 2015), stress (Aronsson 1989), and long-term sick leave (Clausen et al. 2012, 2014). Both low job control in and of itself as well as combined with high job demands are two of only three working conditions graded as having amassed moderate evidence for being related to clinical depression (Theorell et al. 2015). While research on job control has produced comprehensive knowledge on associations between health and job control, it is unclear what employees experience as influence at work and how it relates to the numerous other factors present in actual work situations. As the DCM was developed to analyze the labor market of the 70s, it is also reasonable to assume that the 21 st century work market has brought new conditions for employee influence requiring new conceptualizations (Hvid 2009). Various approaches to shift the balance of the term influence at work have been put forward. Regarding care work, researchers have suggested to include social relations in the DCM (Amble 2013), while others suggests that a new framework more distanced from the model is needed (Sørensen et al. 2007).

We explore this question by unfolding the concept of influence at work beyond its conceptualization as job control. We expand the DCM conception of influence at work to focus on the social relations making up influence at work. We understand influence at work as employee's freedom and ability to impact work tasks and structures. This builds on a sociotechnical foundation, where workers use influence at work to develop meaningful tasks as well as healthy and developing jobs (Hasle \& Sørensen 2013; Thorsrud et al. 1964). We thus expand the concept of influence at work from the focus on influence in work (on how to do a task), most prevalent in applications of the DCM, to include influence over work (on the structural framing of the work), prevalent in Nordic work environment research (Gardell \& Svensson 1981; Hasle \& Sørensen 2013). We examine how employees use their influence in practice and how they relate influence to other elements in their work, both on a task-specific and on a structural 
level. We are interested in the work elements employees relate influence to, as previous studies have shown how organizational logics or technical systems significantly restricts employee's influence or reorient employee's conceptions of influence (Andersen et al. 2020; Kamp \& Dybbroe 2016; Mazmanian et al. 2013). In this article, we focus on employees' abilities to influence the physical design of the workspace, and how physical design of workplaces influence work tasks in return. To understand how influence at work can relate to physical design of workplaces, Väänänen and Toivanen (2018: 2) point to micro-occurrences between employees and organizational structures. They argue that micro-occurrences involving cooperating with co-workers and use of digital calendars ties knowledge workers' influence to temporal structures at workplaces. This kind of tied autonomy offers us the chance to study 'the impact of enabling and restricting structures on individual employees’ (Väänänen \& Toivanen 2018: 4). In the analysis, we show how influence at work is tied to physical design of workplaces in ways that can hinder or enable employee's influence on how to perform tasks. Additionally, we show how employees seek to influence the physical design of workplaces. We place the analysis within a sociomaterial framework, viewing influence at work tied to materiality as sociomaterial assemblages.

\section{Emissions, socio-technical studies, and sociomateriality: materiality in psychosocial work environment research}

Historically, materiality has featured in Nordic work environment research in two ways. One line of research has focused on the harmful effects of materiality in the work environment, particularly emissions, chemicals, noise, and monotonous and straining tasks (Jacobsen 2011). The other line of research took its onset in the sociotechnical studies and has focused on the connectedness of the material organization of the workplaces and social organizing. Famous examples include case studies of the introduction of new technologies in long-wall mining and factory assembly lines (Katz \& Kahn 1978; Trist \& Bamforth 1951). Today, psychosocial work environment research continues to engage with implications for social organization of work as new technology materializes in work settings, including in care work (Ajslev et al. 2019; Ertner 2019). These studies focus on the impact of novel technologies on work techniques, roles, and identities, rather than just the technical implications on workplaces. Still, psychosocial work environment research studies that do focus on physical work design of workplaces are often limited to empirical tests of quantitative associations relating office designs to various health, absence, and productivity outcomes. They show associations between, among other, open-plan offices and increased sick leave and reduced job satisfaction (De Croon et al. 2005; Nielsen \& Knardahl 2020), making it likely that physical design of workplaces and employee wellbeing is related.

Outside of psychosocial work environment studies, interesting links are made between workplace materiality and social organization. Studies on participatory work systems connect employee wellbeing and physical design at workplaces through frameworks that integrate spatial, organizational, technological, and financial aspects to invite workers to join design processes of their workplace aiming for improved ergonomic conditions (Broberg 2010, 2011; Broberg \& Andersen 2016). Studies in environmental psychology emphasize how architecture and physical design evoke emotional responses, 
including in healthcare work (Parsons 1976; Roessler 2012). The idea that work is spatially mediated is well theorized in sociological studies of architecture (Nord \& Högström 2017). Recent work shows how architectural choices - transparent glass walls - in a psychiatric ward reorders care work around the new visibilities. As patients can suddenly see into employee's back office, patients and employees become visible to each other in new constellations, and care work is reordered (Simonsen \& Duff 2020, 2021). This work shows how the physical design of workplaces restructures care worker's tasks and social organization. The notion of 'spatial ordering' is functionalistic in its outset, Simonsen notes, which makes it ill-suited to our ambition of capturing employee's interpretative accounts of practical engagement between the physical design of workplaces and employee's influence. To follow their call to examine the spatial ordering in situated action at workplaces (Simonsen \& Duff 2020), we situate employee influence and workplace materiality in specific work contexts. We examine how materiality is tied to the social concept of influence at work, and how influence at work is tied to workplace materiality. We study them as situated micro-occurrences of daily task performance. To examine both care workers' influence on the physical design of their workplaces, and the physical design of workplaces' impact on care workers' influence, we turn to theories of sociomateriality.

Sociomateriality emerged from studies of human-technology interactions in Information Systems Research to occupy a theoretical middle position between Science and Technology Studies' focus on relations and practice theory's focus on people's concrete practices (Leonardi 2012; Orlikowski \& Scott 2008). The framework acknowledges materials' capabilities to act, found in post-humanist approaches like ANT, and acknowledges the primacy of human agency over non-humans, reflected in humanist traditions, like structuration theory (Giddens 1984; Latour 2005; Orlikowski 2005). A sociomaterial framework allows us to consider the material aspects of a social concept like influence at work, and the social aspects of workplace materiality. To examine entwinement of materiality and influence, we conceptualize them as sociomaterial assemblages. Sociomaterial assemblages are dynamic collections of social and material activity that emerge as integrated parts in practice. Importantly, there is no separation between social and material aspects within sociomaterial assemblages. Rather, social and material concepts constitute the sociomaterial assemblage (Orlikowski 2010). By firstly theorizing care workers' tasks as situated micro-occurrences of influence tied to materiality and secondly framing tied influence as sociomaterial assemblages, we achieve two things. First, we account for how we can study both how workplace design can affect employee's influence on tasks and how employees can influence workplace design. These becomes two sides of the same phenomenon when we view influence and materiality as co-constituting sociomaterial assemblages. Second, we enable ourselves to analyze social and material aspects simultaneously in our analysis of relations between influence and materiality. By considering these concepts together from a sociomaterial perspective, we hone in on how materiality and influence are entangled in each other (Orlikowski 2007). We are interested in how influence and materiality are entangled in sociomaterial assemblages and how the interrelation affects the work environment. We analyze how physical design of workplaces hinder or enable task performance for employees by hindering or enabling their influence. Simultaneously, we analyze how employees influence the physical design of the work environment in varying degrees. 


\section{Methods}

\section{Data collection}

Interactions between materiality and social organization in psychosocial work environment research have typically been studied in relation to workers in industrial production (Katz \& Kahn 1978; Trist \& Bamforth 1951), while fewer studies have addressed such interactions in care work. For this study, we have collected interview data from three care work workplaces.

Interviewed workplaces were recruited to cover different care work activities in both the private and public sector (see Table 1) in an information-oriented selection (Flyvbjerg 2006). Focus group participants were employees engaged in the primary task of the organization, and single interviews were with immediate managers with personnel responsibility. We have conducted three focus group interviews (total 15 participants) in three Danish care workplaces and three single interviews with interview participants' managers (total five participants). Interviews were conducted at the work site, in Danish.

Table I Workplaces interviewed

\begin{tabular}{llclccc}
\hline \multicolumn{6}{c}{ Workplaces interviewed } \\
\hline$\#$ & Workplace & Sector & $\begin{array}{l}\text { Size of } \\
\text { organization }\end{array}$ & $\begin{array}{c}\text { No. of } \\
\text { employees } \\
\text { interviewed }\end{array}$ & $\begin{array}{c}\text { No. of } \\
\text { managers } \\
\text { interviewed }\end{array}$ & $\begin{array}{l}\text { Type of } \\
\text { care work }\end{array}$ \\
\hline I & $\begin{array}{l}\text { Childcare } \\
\text { Institution Workers }\end{array}$ & Public & $<50$ employees & 5 & 1 & Childcare \\
2 & $\begin{array}{l}\text { Adult Disability } \\
\text { Care Workers }\end{array}$ & Private & $<50$ employees & 4 & 3 & $\begin{array}{l}\text { Adult } \\
\text { disability care }\end{array}$ \\
3 & $\begin{array}{l}\text { Hospital Nurses } \\
\text { Hublic }\end{array}$ & $>1000$ employees & 6 & 1 & Healthcare \\
\hline
\end{tabular}

Two researchers conducted focus group interviews in two-hour sessions. One researcher primarily focused on facilitating the conversation, and the other researcher observed and probed additional questions (Cassell \& Symon 2004). Focus groups were conducted in a semi-structured format, based on an interview guide but allowing other topics to emerge. Interviews asked to participants' immediate conception and experiences of influence at work, whether they feel they have sufficient influence to perform primary tasks, and what factors impacted their level of influence. We chose focus groups as a method to enable group discussions around shared experiences of work that might be interpreted differently among employees. More than documenting several views of influence at work simultaneously, the aim of focus groups was to bring these issues up for shared discussion, reflection, and contestation to view interpretations and social dynamics at work (Brinkmann \& Tanggaard 2015; Cassell \& Symon 2004). Points raised in focus groups were hereby validated by the participants in cooperation as shared experiences (Bradbury-Jones et al. 2009). Our method allowed us to collect verbal recounts of experiences of micro-occurrences of influence at work in detailed examples.

Interviews with managers lasted one hour and asked to the organizations' primary tasks and management systems, managers' perception and experience of influence at work, as well as their thoughts about maintaining a suitable level of influence 
for employees. The first author conducted the manager interviews. Manager interviews generated information on managers' perceptions and experiences as well as contextual information on the focus group interviews, among them the specificities of the work, tasks, and team.

\section{Data analysis}

The first author grouped data material from focus groups and interviews with managers in Nvivo11 according to thematic categories (Boyatzis 1998). Thematic categories were developed by the first and last author in a workshop-format by a combination of preestablished categories based on the literature on influence and materiality and categories emerging from reading and re-reading interviews. First author has translated interview quotes to English.

\section{Findings}

We present findings on the relations between care workers' influence and workplace materiality from three cases. Case 1 show A) how childcare employees try to influence the physical design of the childcare institution unsuccessfully, and B) how the physical design of the institution hinder childcare employees influence on how to perform primary tasks. Case 2 show A) how adult disability care employees succeed in influencing the physical design of their workplace, and B) how the physical design of the workplace enables employees to perform primary tasks. Case 3 show A) how the physical design of the workplace enables nurses to perform their primary tasks, but hinders them in performing other tasks. We summarize the cases in a table at the end of this section.

\section{'That damn house': childcare work hindered by physical design of workplace}

In a new build in a Copenhagen suburb, with construction still ongoing both indoors and outdoors, over 100 children arrive each morning to play, learn, and eat. The childcare institution employs about 35 individuals, including trained childcare workers, childcare assistants, and temporary assistants. It is divided into a nursery and a kindergarten. As we conduct the focus group interview in the lunchroom, the childcare employees elaborate on the condition of the building. The move to a new building had defined the past year at the childcare institution. Employees and the manager had spent time in design meetings with architects at the municipality to provide input to the prestigious new building, but with few results.

Well, we went to a lot of meetings that we spent a lot of time on [...] We really had a lot of objections. Not one of them was listened to. We sat at the table with architects, with people from the municipality, with quite many ... but there's nothing, not even things like power outlets did they listen to - the fact that it's very unwise to have them at floor 
level ... and, well, this is stuff we know. We know these things: you have to be able to seal the playground off, there can't be power outlets [at the floor], there must be gates between [playground and staircase] ... two toilets are not sufficient. None of this [did they listen to]. None of it is visible to me at all.

Childcare institution worker \#3, focus group interview

The childcare workers' inputs were not incorporated into the new childcare building. The finished building did in fact contain power outlets within children's reach, an insufficient number of toilets, and playground areas without gated staircases. These, by employees' professional standards, basic considerations were not incorporated into the building and employees had to change work routines in order to avoid the safety hazards posed by these issues. With children queued up to use toilets, potentially wandering into dangerous playground areas and possibly interacting with power outlets, childcare workers experience that the building opposes their efforts to provide safe care for the children as it limits their professional discretion. Dysfunctional tools and spaces pose obstacles rather than enabling employees conducting their primary task. This generated frustration for the employees to the extent that it affected their work environment. The employees explicitly connect the dysfunctional building with the problematic work environment in the work group with the characterization of the childcare institution as 'that damn house':

Well, they [construction workers] had to drain the playground because they drove such heavy things [vehicles] and they haven't turned the soil [afterwards], so the children could drown on the playground! Well! And this is the aftermath we are stuck with. [...] And that is why ... it affects our work environment that damn house - it's definitely why it still haunts us. That the things don't work, that the things aren't repaired.

Childcare institution worker \#5, focus group interview

Ultimately, the childcare workers related the house to sickness absence:

(\#2): I think that you can feel it in terms of - I think this is a house with a lot of sickness in it. Maybe some of it is a delayed reaction to the pressure we've been under - at least the two years that I've been here. I believe so, it might be it.

$(\# 5)$ : We are a house in which we have taken turns to experience breakdowns. We really are.

Childcare institution worker \#2 and \#5, focus group interview

Employees' experience working under such restrictions as a pressure that breaks them down, resulting in widespread sickness absence and generally detrimental working conditions, encapsulated in the notion of 'that damn house'. On top of this, the fact that employees initially were offered to voice their opinions on the design made the daily experience of working in a building that hindered their work absurd. Representatives had been formally invited to provide professional input to design the building, but were denied any real impact. The childcare workers first laughed and then resigned at this experience, as they reported their lack of influence on the building. Ultimately, the futile invitation to influence building design as well as the experience of everyday work under the restrictions posed by the building had implications for childcare workers' perceptions of themselves and their job: 
(\#3): As we sat in this process with this 'building show', it became very apparent that they are not able [to listen]. It was ... not even the woman from the parent board did they listen to. You might as well not listen, it wouldn't matter. It wasn't ... just didn't matter, it wasn't worth anything.

Interviewer: did they pretend to listen?

(\#3): No, no, no ... Not even that! They didn't have that much courtesy!

(\#4): And it's just an extreme pity, this, because it enables you to think, that I think: 'am I where I should be?'

Childcare workers \#3 and \#4, focus group interview

Childcare employees experience the lack of influence on the design of the building as not being listened to, as lack of courtesy, as diminishing their professional judgement, and in sum that their professional expertise and input 'just didn't matter' and 'wasn't worth anything'. Such a paradoxical involvement is experienced as harmful for employees' attachment to the workplace and to the worth of their professional expertise.

\section{'Great soil to grow in': adult disability care work enabled by physical design of workplace}

Located in idyllic rural settings, the care center for adults with disabilities is a private foundation rooted in holistic pedagogical principles. It refers to itself as a 'living-community' integrating disabled and non-disabled people in daily work and living arrangements. After interviewing employees, researchers were given a tour of the facilities including common areas, houses where several adult disabled citizens live together, a bakery, dairy, nursery, and art workshop functioning as workplaces for disabled citizens where they produce artisanal products. In the focus group, an employee explains that the employee group has in fact endless influence on the design of the buildings at the workplace:

Well, we continuously have mandate groups and things that go into committees. [...] Among other things - you can see behind you: 'The new living community'. Who have taken lead on deciding color of the tiles, on the building envelope, on textiles, on lighting, on ... well, it's just an example. So there's things going in committees all the time. The excitement and the abilities and the will drive it, and the economy present, and, first of all, the residents' wishes.

Adult disability care worker \#2, focus group interview

The example illustrates how employees in the living-community have great influence on decisions regarding properties of the buildings. Any employee with enthusiasm and ability can influence any design of the new building. This approach was evident in the buildings already constructed. Employee committees had collaboratively decided on design, and several of the private houses built on the site even belonged to employees who had designed and projected their private residences. Employees were able to influence their tasks significantly, but they required initiative and effort of each other to do so. An employee illustrated the principle: 
(\#2): There's not really much that can't be done. You'll have a great idea. The question is, are you able to get others on board with the great idea that you had? Because, then there isn't much ... 'Should we have pigs?' 'Yes!' 'Who'll take care of it?' 'Good, if no one signs up then, no pigs', right? But if there's five [people] who want to be responsible for caring for them in weekends, then we'll have pigs'.

(\#3): And then we damn well know who to call when they run off!

Adult disability care worker \#2 and \#3, focus group interview

Employees had great discretion to solve their primary tasks and were free to conduct disability care as they saw fit. If employees felt this demanded that they acquired pigs, then they were free to construct the necessary structures. Employees characterized their experience of working this way as freedom:

When I'm at work, I really do feel like I'm free to launch all kinds of projects. Those who are to judge, that's the residents. Whether I really do the things that I've promised. Whether they benefit from them [...] and they think that it's fun, stuff like that. But I'm free to launch the projects that I actually want to, and really I'm free to administer my work time and free time as I want to. You know, there is no handbook out here.

Adult disability care worker \#1, focus group interview

Whether the residents benefit and are happy guides the employee in his daily work. This drive originating in residents' wellbeing has guided employees at the living-community over the years to oversee the construction of a bakery, dairy, nursery, art workshop, and more, to provide engaging care for the residents according to the living-community's values. As the buildings have been constructed for the purpose of engaging residents and designed by employees, employees did, not surprisingly, find them enabling for their work. Asked how the experience of working at such a site, an employee responded:

It is a very enabling environment to grow in. It is a very healthy environment to grow in as a human being. Because you are provided opportunities for growth all the time, and the basis that you have to grow within, it is so well composted - or, how should I put it - it is such great soil to grow in.

Adult disability care worker \#1, focus group interview

Employees experienced working in an environment of enabling material structures as a healthy work environment that enables, not only facilitation of the primary task, but also integrated personal and professional growth.

\section{'Earplugs on the ward': Employee influence enabled and hindered by physical design of workplace}

Interviewed nurses work in an ambulant ward in a large hospital organization in a regional town. Although the hospital is expanding its facilities, the nurses have worked in this particular ward a long time without experiencing major re-designs of the physical setting. Patients arrive throughout the day to take a seat in the waiting room until they go to receive treatment in large rooms further down the ward. Nurses are mostly 
sat at the equipment in large rooms at the back, and fan up and down the ward to collect patients, exchange information, and perform administrative tasks. Asked directly on their experience of their influence to perform primary tasks, nurses highlight managerial and organizational structures as relevant:

(Interviewer): Do you experience that you are afforded the influence required to perform the primary task?

[we have sufficient influence] in the day-by-day ... You can feel a bit powerless in periods because of what comes from above is ... there's things coming that the hospital management want to work on. It is without consideration to how much we have going on in the department. So, in some periods you can feel that there's no room to develop on the things that we think is important or relevant for our department. So things can go all stale because of things coming from above, like cost effective measures or increased effectiveness or ... Nurse \#1, focus group interview

Nurses generally think they have sufficient influence to conduct their primary tasks in the daily work on the ward. They mention organizational restructurings introduced by the management as a disruptor of their influence to perform primary tasks. Nurses also experience restrictions on their influence from the departments' medical doctors. Doctors have the final authority regarding treatment, which occasionally restricts nurse's influence:

The problem is when doctors do not quite agree on how to go about it [treatment]. Actually, that's a big problem. Our room for maneuvering is very dependent on the particular doctor. There's definitely some doctors that absolutely respect there's knowledge among the nurses that might exceed their own in some areas. Others more have that: 'I'm the doctor. This is how it is' ... I think, generally, and compared to other departments, we been pretty free ... That's also why it's so important that we are heard when there is uncertainties. That's how we go about it.

Nurse \#4, focus group interview

Overall, nurses report a high degree of influence on their primary tasks, treating and caring for scheduled patients, but occasionally their influence is restricted by organizational restructurings and professional verdicts of doctors. The nurses generally accept these restrictions. Organizational restructurings are accepted as a condition of hospital work, and doctor's interferences are accepted because nurses feel heard in the decision-making. When restrictions on their influence to perform tasks becomes problematic, it is related to adjacent tasks such as administrative tasks, mandatory organizational courses, and professional development tasks. The nurses work in a hospital organization with high focus on professional development, but struggle to find the space to engage with such tasks on the ward:

Interviewer: Do you have offices or places here to sit and do this kind of work [professional development tasks]?

(\#1): Not really. We have a single room with two computers, but the students sit there.

Then we have our stations were we sit to work -

(\#3): - I think we really do lack physical environments [for this]! 
(\#1) Yes, we do!

(\#3): It's hard to find silence sometimes! Hard to finish stuff ... I took this mandatory e-learning course by my computer in this room while a colleague had a phone conversation, and I sit with earplugs in, and I have to focus on this transfusion medicine and fire extinguishing and what not, and ... well, you get interrupted, or you hear ... you are not withdrawn.

Nurses \#1 and \#3, focus group interview

Working on a hospital ward designed for patient care tasks, nurses have trouble performing mandatory tasks such as professional development and organization courses. The nurses lack a dedicated space, for example quiet rooms, and dedicated tools, for example computers. Not being able to withdraw to work on tasks that require concentration hinders their influence to perform tasks. The physical design of the ward hinders employees' influence to perform administrative tasks, but does not hinder nurses in performing their primary tasks. The case thus opens for a task-specific relation between employee influence and materiality. The case also shows how the physical design of the workplace is not necessarily experienced as intimate to employees' work environment and wellbeing as case 1 and 2 suggests. Rather, case 3 shows how nurses keep a pragmatic attitude focused on the task at hand and relate their lack of influence to their wellbeing or work environment to a lesser extent. Additionally, the case shows how nurses' influence is hindered by the social organization of the hospital, but in ways that the nurses accept.

\section{Summary of findings}

We present the findings from case 1, 2, and 3 here.

Table 2 Summary of findings in case 1, 2, and 3

\begin{tabular}{|c|c|c|}
\hline $\begin{array}{l}\text { Case I: Childcare Institution } \\
\text { Workers }\end{array}$ & $\begin{array}{l}\text { Case 2: Adult Disability } \\
\text { Care Workers }\end{array}$ & Case 3: Hospital Nurses \\
\hline $\begin{array}{l}\text { Influence on tasks is hindered by } \\
\text { building }\end{array}$ & $\begin{array}{l}\text { Influence on tasks is enabled } \\
\text { by building }\end{array}$ & $\begin{array}{l}\text { Influence on primary tasks is } \\
\text { enabled by building } \\
\text { Influence on professional develop- } \\
\text { ment tasks is hindered by building }\end{array}$ \\
\hline $\begin{array}{l}\text { Pseudo-influence on building design } \\
\text { harmful for professional worth and } \\
\text { attachment to workplace }\end{array}$ & $\begin{array}{l}\text { Real influence on building } \\
\text { design, planning, and erection } \\
\text { increases wellbeing }\end{array}$ & $\begin{array}{l}\text { No influence on building design, no } \\
\text { expectation of influence }\end{array}$ \\
\hline Call the workplace 'damn house' & $\begin{array}{l}\text { Call the living-community } \\
\text { 'great soil to grow in' }\end{array}$ & $\begin{array}{l}\text { Provides no characterization of the } \\
\text { building beyond its practical use }\end{array}$ \\
\hline $\begin{array}{l}\text { Relate building to problematic work } \\
\text { environment, sickness absence }\end{array}$ & $\begin{array}{l}\text { Relate buildings to personal } \\
\text { growth }\end{array}$ & $\begin{array}{l}\text { Do not relate the building to } \\
\text { personal or professional wellbeing }\end{array}$ \\
\hline
\end{tabular}

\section{Discussion}

The cases presented above show how interviewed employees relate influence at work to the physical design at workplaces. Childcare institution employees' influence on how 
to perform tasks was hindered by the placement of power outlets, the number of bathrooms, and hazardous outdoor areas. In contrast, the buildings available to disability care workers enabled employee influence on how to perform their tasks. The physical design of the ward enabled nurse's primary task, but hindered their influence on how to do professional development tasks. We find two main points in the cases: 1) employee influence is tied to materiality at workplaces, and 2) influence is tied to materiality in both enabling and hindering ways for employee task performance. This may differ according to the specific task.

We examine both how workplace materiality hinder or enable employee's influence on how to do tasks, and how employees influence workplace design. To do this, we frame the materiality at workplaces and influence at work within a sociomaterial framework. This means that we see materiality and influence not as two isolated and fundamentally different entities, but as co-constituting parts of a whole - as sociomaterial assemblages that emerge as care workers engage materiality and influence in practice through everyday tasks. Taking examples from our cases, we see these assemblages emerge in childcare employees keeping children away from power outlets, employees working with adult disability residents in workshops, and nurses moving from patient treatment stations to makeshift computer offices. We find that the way materiality and influence is configured in the sociomaterial assemblage among childcare employees hinder task performance. In contrast, the sociomaterial assemblage of influence and materiality among adult disability care employees enable task performance. Among nurses, they hinder some tasks but enable primary tasks. We discuss effects of the sociomaterial assemblages on employees' psychosocial work environment in the following section.

\section{Employee's experiences of workplace materiality enabling or hindering influence}

Childcare institution employees told of widespread stress among the employees, sickness absence, and lack of attachment to the workplace and the profession. They related this to working in a building that hindered their task performance. It seems that being hindered in task performance on a daily basis put a strain on the childcare employees. This is shown among other groups of care workers as well (Andersen et al. 2020). Childcare employees explained that a part of this strain was caused by the fact that they were invited to voice their opinion on the building design, but realized that their input was ignored. Research shows the importance of voice and involvement for job satisfaction and employee retention (Cox et al. 2006; Spencer 1986), which substantiates the employees' negative experience. Additionally, the fact that childcare institution employees experienced this as disregard for their professional input can be seen as a threat for their self-esteem as professionals. By rendering their professional knowledge illegitimate, the involvement itself might function as a source of stress (Semmer et al. 2007). Among the disability care employees, the experience of influence at work was freeing, provided great opportunities for personal growth, and fostered an organic, lasting attachment to the workplace. We note the disability care employees' emphasis on the 'resident's needs' as a guide for how to administer their work. Extensive studies show how freedom to engage with primary tasks in a meaningful manner brings benefits for employee job satisfaction, productivity, meaning, and attachment (Ravn 2008; Sasser \& 
Sørensen 2016; Sørensen 2008). Primary tasks can both refer to the functional task of the organization (Rice 1963), disability care, but also to the tasks that employees themselves have defined as the most meaningful in their work (Sasser \& Sørensen 2017) here, 'resident's needs'. It seems that disability care employees are enabled to define their primary tasks in this case. Learning from other studies, we suggest that this additionally enables them to perform their professional identity by engaging with meaningful tasks (Kamp 2011). We argue that disability care employee's positive experience of working in 'freedom' is related to being able to define primary tasks and to engage with them in a meaningful manner. We argue that this 'freedom' is a result of the high degree of influence they are enabled in their work, including in the physical design of their workplace. Nurses experienced generally sufficient influence on how to perform primary tasks. When nurse's influence to perform primary care task was hindered it was due to the social organization at the hospital. Our findings fall well within previous research on the dynamics of organization and different professional expertises and effects on employees' professional identities within healthcare work (Andersen et al. 2020; Hasle 2014; Kamp \& Dybbroe 2016;). In our case, nurses accept that doctors interfere in their work as long as nurses are 'heard'. We suggest that nurses are capable of maintaining their professional identity because they are offered a voice in the discussion (Spencer 1986).

The studies quoted above, along with studies on the temporal restrictions of care work (Tufte 2013; Tufte \& Dahl 2016), give light to critical research areas on care work. This article, however, focus on the effect of materiality at workplaces. Workplace materiality has been shown to effect elder care worker's professional identities through employee's appraisal of client's homes (Laulainen \& Hujala 2016). There is less knowledge on the relation between workplace materiality and employee influence in care work. We show how materiality at workplaces enable or hinder employee's influence to perform tasks in different ways. In addition, we show three examples of how employees seek to influence, or not, the physical design of the workplace. In case 1, childcare employees were invited to design their new building, but denied real influence. Once the building was designed, their influence was minimal. In case 2, adult disability employees influenced buildings on the site daily in an ongoing process. They can alter existing structures or design new ones. In case 3, nurses did not seek nor were invited to influence the building. The hospital ward was a given that they did not concern themselves with altering.

\section{Influence at work and workplace materiality tied in sociomaterial assemblages}

By approaching influence tied to materiality as sociomaterial assemblages, we situate (Orlikowski 2005) employee influence in the social organization and physical design at workplaces. A situated view of influence emphasizes the specific context around employees' practical engagements of influence at work. Here, we are in line with recent work on stress in cultural psychology, where Kierkegaard (Kirkegaard 2015; Kirkegaard \& Brinkmann 2016) has introduced the notions collective stress and distributed stress to clarify how employees' appraisal of and coping with stress is related to how co-workers appear to be coping as well as physically embedded in buildings and electronic calendars. Kierkegaard argues that

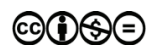


these different appraisal and coping practices are deeply embedded in the concrete context in the sense that the different aspects of working environment such as the physical and cultural characteristics both separately and combined invite the employees to engage in distinct appraisals and coping practices and limit the use of others. (Kirkegaard \& Brinkmann 2016: 12)

Similarly, employing the concept sociomateriality, we have located influence at work in the embedded work context of our cases. We view influence at work and physical design at care workplaces as co-constitutive of sociomaterial assemblages. This allows us to understand how physical workplaces effect employee's influence on how to perform tasks, as well as how employees' influence workplace physical design. As we regard employees influencing physical design as both social and material, and the physical designs' effect on employee influence as both social and material, the distinction between them blurs.

Approaching influence at work as simultaneously a material and social phenomenon has illuminated new elements in the work context that hinder or enable employee influence. Current research seeking to integrate materiality with psychological and social organizations in the psychosocial work environment tend to examine newly introduced technology (Ajslev et al. 2019; Ertner 2019). We show how mundane parts of workplaces, buildings, and spatial arrangements within buildings can hinder or enable employee's influence on how to perform tasks. The focus on mundane materials is also taken up in work environment studies applying Actor-Network-Theory (ANT) analyses of postal and industrial workers to show how work environment phenomena like weather, vehicles, and machines emerge when approaching them as sociomaterial assemblages (Abildgaard \& Nickelsen 2013; Mogensen 2012; Nickelsen 2008). These studies argue that materiality matters for the formation, appraisal, and handling of work environment issues. We agree, but focus on how the physical design of workplaces interacts with influence at work to produce effects in the work environment. Our study thus compliments lines of research, which have found the built environment relevant for care work (Nord \& Högström 2017). Such studies often theorize workplace physical design as systems of ordering. Simonsen's work show how physical design mediates healthcare work via spatial orderings inherent in the design (Simonsen \& Duff 2020, 2021; Wilhelm \& Battisto 2020). These studies show how materiality can matter for workers' identities, organization, and tasks. While this is important, we have zoomed in on what happens in the practical engagements of workplace design and care workers performing tasks to argue that materiality matter for employee influence.

On basis of these cases on sociomaterial assemblages of influence at work and materiality at workplaces in care work, we encourage future research to study employee's experiences of the relation between influence at work and workplace materiality. We have shown that this aspect is important in care work today.

\section{Strengths and limitations}

This study has applied focus group interviews and single interviews to unveil a relation between influence at work and materiality in Danish care work. Most interviews included a tour of the workplace where interviewees presented their workstations and other places of interest. This allowed researchers to observe the physical design at the 
workplace and how employees engaged with it at the time of interviewing only. From our method follows that our data material is people talking about experiencing influence at work and its relation to materiality, and not observations or participations in such interactions. As such, our findings are based on employee's narrations of experiences of influence at work and its relation to materiality. As we did not employ ethnographic fieldwork, we were not able to complement the interview data with observations of micro-occurrences of influence at work throughout participant's workday. We hope that future studies will look at how employees interact with the materiality at work, for instance by applying prolonged field-based research at workplaces.

We acknowledge the possibility that a varied sample of workplaces might cloud our findings by presenting issues related more to the specific organization of work found at the workplace than to issues of general importance to influence at work. We are presenting empirical issues related intimately to the context of specific workplaces. We do not attempt to make it representative of the workplace, care work, or the Danish labor market in general. Rather, we are extracting themes for discussing experiences of influence at work relevant for care work in Denmark, with the character of the work force that follows in regards to employee characteristics (i.e., gender, age) and social organization of the work (i.e., power dynamics, management systems). Given our focus on care work, our conclusions can be more relevant for female dominated work, team-based work, and work with high emotional engagement.

\section{Conclusion}

In this article, we explored the relationship between influence at work and materiality in the experience of Danish care workers. Based on focus group interviews and single interviews with managers in three job groups, we found relations between materiality at workplaces and influence at work. We have argued that employee's experiences of influence are tied to the materiality of the work setting. This way we expand influence at work beyond something exerted by employees on co-workers to something working in relation to materiality at workplaces. We find that material settings may both hinder and enable employee's influence on how to perform tasks, and we find that this can be taskspecific. We find that employees in our cases do also seek to influence the materiality at workplaces. We link employees' negative experiences of having their influence hindered and positive experiences of having their influence enabled to recent studies on psychosocial work environment in care and health-care work. Theoretically, we have applied a sociomaterial framework to study influence at work and materiality at workplaces as co-constituting entities. Approaching influence as a sociomaterial phenomenon, we argue for the potential of a sociomaterial perspective to integrate materiality in psychosocial work environment research. Such a perspective illuminates new elements in the work context that hinder or enable employee influence. In this article, we show how buildings and spatial arrangements within buildings are significant co-constituents of employee influence. On the basis of this study, we suggest that employee influence might be wide-ranging in theory, but in practice is tied to contextual factors at workplaces like materiality that might enable or hinder influence. We suggest that a greater focus on contextual factors, including materiality, at workplaces has much to offer psychosocial work environment research.

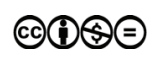




\section{References}

Abildgaard J. S. and Nickelsen N. C. (2013). Making materials matter - a contribution to a sociomaterial perspective on work environment, Nordic Journal of Working Life Studies 3: 63-84. doi: https://doi.org/10.19154/njwls.v3i4.3073.

Ajslev J. Z., Johansen H. H., Andersen M. F., et al. (2019). Occupational identities and physical exertion in (re)configurations of new technologies in eldercare, Nordic Journal of Working Life Studies 9: 19-37. doi: https://doi.org/10.18291/njwls.v9i4.117778.

Andersen M. F., Ajslev J., Tanggaard L., et al. (2020). Skakmat - kan prisen for indflydelse blive for stor? Skyggearbejde og workarounds blandt ansatte i psykiatrien [Checkmate Can the cost of influence become too great? Shadowwork and workarounds among employees in psychiatry], Tidsskrift for Arbejdsliv 22: 9-24.

Amble N. (2013). Autonomy and control when working with humans - a reflection on sociotechnical concepts, Nordic Journal of Working Life Studies 3: 45-62. doi: https://doi. org/10.19154/njwls.v3i4.3072.

Aronsson G. (1989). Dimensions of control as related to work organization, stress, and health, International Journal of Health Services 19: 459-468. doi: https://doi.org/10.2190/n6kqhwa0-h7cj-kupq.

Bolin M. and Olofsdotter G. (2019). Bringing organizations back in: going from healthy work to healthy workplaces, Nordic Journal of Working Life Studies 9: 3-17. doi: https:// doi.org/10.18291/njwls.v9i4.117779.

Boyatzis R. E. (1998). Transforming Qualitative Information: Thematic Analysis and Code Development, Thousand Oaks: SAGE.

Bradbury-Jones C., Sambrook S. and Irvine F. (2009). The phenomenological focus group: an oxymoron? Journal of Advanced Nursing 65: 663-671. doi: https://doi.org/10.1111/ j.1365-2648.2008.04922.x.

Brinkmann S. and Tanggaard L. (2015). Kvalitative Metoder. En Grundbog [Qualitative methods. A text-book], København: Hans Reitzel.

Broberg O. (2010). Workspace design: a case study applying participatory design principles of healthy workplaces in an industrial setting, International Journal of Technology Management 51: 39-56. doi: https://doi.org/10.1504/IJTM.2010.033127.

Broberg O. (2011). Enabling Objets for Participatory Design of Socio-Technical Systems. In: Culley, S. J., Hicks, B. J., McAloone, T. C., Howard, T. J., Badke-Schaub, P. (ed) DS 68-7: Proceedings of the 18th International Conference on Engineering Design (ICED 11), Impacting Society through Engineering Design. Lyngby/Copenhagen, Denmark.

Broberg O. and Andersen S. N. (2016). Brugerdreven simulation i design af arbejdssystemer i hospitalssektoren: Et nyt virkemiddel i den forebyggende arbejdsmiljøindsats [Userdriven simulation in design of work-systems in the hospital sector: a new tool in preventative work evironment work]. Danish Technical University (DTU).

Cassell C. and Symon G. (2004). Essential Guide to Qualitative Methods in Organizational Research, London: SAGE.

Clausen T., Burr H. and Borg V. (2014). Do psychosocial job demands and job resources predict long-term sickness absence? An analysis of register-based outcomes using pooled data on 39,408 individuals in four occupational groups, International Archives of Occupational and Environmental Health 87: 909-917. doi: https://doi.org/10.1007/s00420-014-0936-7.

Clausen T., Madsen I. E., Christensen K. B., et al. (2019). The Danish Psychosocial Work Environment Questionnaire (DPQ): development, content, reliability and validity, Scandinavian Journal of Work, Environment \& Health 45: 356-369. doi: https://doi.org/ 10.5271/sjweh.3793.

Clausen T., Nielsen K., Carneiro I. G., et al. (2012). Job demands, job resources and long-term sickness absence in the Danish eldercare services: a prospective analysis of register-based 
outcomes, Journal of Advanced Nursing 68: 127-136. doi: https://doi.org/10.1111/j.13652648.2011.05724.x.

Cox A., Zagelmeyer S. and Marchington M. (2006). Embedding employee involvement and participation at work, Human Resource Management Journal 16: 250-267. doi: https:// doi.org/10.1111/j.1748-8583.2006.00017.x.

De Croon E. M., Sluiter J. K., Kuijer P. P., et al. (2005). The effect of office concepts on worker health and performance: A systematic review of the literature, Ergonomics 48: 119-134. doi: https://doi.org/10.1080/00140130512331319409.

De Spiegelaere S., Van Gyes G. and Van Hootegem G. (2016). Not all autonomy is the same. Different dimensions of Job Autonomy and their relation to work engagement \& innovative work behavior, Human Factors and Ergonomics in Manufacturing \& Service Industries 26: 515-527. doi: https://doi.org/10.1002/hfm.20666.

Ertner M. (2019). Enchanting, evoking, and affecting: the invisible work of technology implementation in homecare, Nordic Journal of Working Life Studies 9: 33-47. doi: https:// doi.org/10.18291/njwls.v9iS5.112690.

Flyvbjerg B. (2006). Five misunderstandings about case-study research, Qualitative Inquiry 12: 219-245. doi: https://doi.org/10.1177/1077800405284363.

Gardell B. (1977). Arbetsinnehåll Och Livskvalitet: En Sammanställning Och Diskussion Av Sambällsvetenskaplig Forskning Rörande Människan Och Arbetet [Job Content and Quality of Life: A Collection and Discussion of Social Science Research Concerning People and Work], Stockholm: Prisma.

Gardell B. and Svensson L. (1981). Medbestämmande och Självstyre: En Lokal Facklig Strategi för Demokratisering av Arbetsplatsen [Influence and self-management: A local, professional strategy for democratizitation of the workplace], Stockholm: Prisma.

Giddens A. (1984). The Constitution of Society: Outline of the Theory of Structuration, Cambridge: Polity Press.

Hackman J. and Oldham G. (1976). Motivation through the design of work: test of a theory, Organizational Behavior and Human Performance 16: 250-279. doi: https://doi. org/10.1016/0030-5073(76)90016-7.

Hasle P. (2014). Lean og professionel autonomi på hospitaler, Tidsskrift for Arbejdsliv 16: 67-82. doi: https://doi.org/10.7146/tfa.v16i1.108955.

Hasle P. and Sørensen O. H. (2013). Employees as individually and collectively acting subjects - key contributions from Nordic working life research, Nordic Journal of Working Life Studies 3: 9-30. doi: https://doi.org/10.19154/njwls.v3i3.3009.

Hvid H. (2009). To be in control - vejen til godt psykisk arbejdsmiljø, læring og innovation? [To be in control - the road to beneficial mental working environment, learning and innovation?] Tidsskrift for Arbejdsliv 11: 11-30. doi: https://doi.org/10.7146/tfa. v11i1.108763.

Jacobsen K. (2011). Velfordens Pris: Arbejderbeskyttelse og Arbejdsmiliø gennem 150 àr [The price of Welfare: Worker protection and Work Environment through 150 years], Copenhagen: Gads Forlag.

Kamp A. (2011). Mening i arbejdet - for lidt, for meget, til forhandling? [Meaning in work too little, too much, too be negotiated?], Tidsskrift for Arbejdsliv 13: 8-27. doi: https:// doi.org/10.7146/tfa.v13i2.108883.

Kamp A. and Dybbroe B. (2016). Struggles of professionalism and emotional Labour in standardized mental health care, Nordic Journal of Working Life Studies 6: 67-86. doi: https://doi.org/10.19154/njwls.v6i1.4886.

Karasek R. (1979). Job Demands, Job Decision Latitude, and Mental Strain: implications for Job Redesign, Administrative Science Quarterly 24: 285-308. doi: https://doi.org/ 10.2307/2392498. 
Karasek R., Baker D., Marxer F., et al. (1981). Job Decision Latitude, Job Demands, and cardiovascular disease: a prospective study of Swedish men, American Journal of Public Health 71: 694-705. doi: https://doi.org/10.2105/ajph.71.7.694.

Karasek R. and Theorell T. (1990). Healthy Work: Stress, Productivity, and the Reconstruction of Working Life, New York: Basic.

Katz D. and Kahn R. L. (1978). The Social Psychology of Organizations, New York: Wiley.

Kirkegaard T. (2015). Stress as a sociocultural phenomenon: exploring the distributed nature of stress in an organizational context. 1. ed. Aalborg: Aalborg University Press. doi: https://doi.org/10.5278/vbn.phd.hum.00013.

Kirkegaard T. and Brinkmann S. (2016). "Which coping strategies does the working environment offer you?" a field study of the distributed nature of stress and coping, Nordic Psychology 68: 12-29. doi: https://doi.org/10.1080/19012276.2015.1045543.

Kivimäki M., Nyberg S. T., Batty G. D., et al. (2012). Job strain as a risk factor for coronary heart disease: a collaborative meta-analysis of individual participant data, The Lancet 380: 1491-1497. doi: https://doi.org/10.1016/S0140-6736(12)60994-5.

Latour B. (2005). Reassembling the Social, an Introduction to Actor-Network-Theory, Oxford New York: Oxford University Press.

Laulainen S. and Hujala A. (2016). Material construction of care workers' identity, Nordic Journal of Working Life Studies 6: 7. doi: https://doi.org/10.19154/njwls.v6i1.4883.

Leonardi P. M. (2012). Materiality, Sociomateriality, and Socio-Technical Systems: What Do These Terms Mean? How are they different? Do we need them? In: Leonardi P. M., Nardi B. A., \& Kallin, J. (eds) Materiality and Organizing: Social Interaction in a Technological World, Oxford: Oxford University Press.

Madsen, I. E. H., Nyberg, S. T., Magnusson Hanson, L. L., Ferrie, J. E., Ahola, K., Alfredsson, L., ... Kivimäki, M. (2017). Job strain as a risk factor for clinical depression: systematic review and meta-analysis with additional individual participant data, Psychol Med 47(8), 1342-1356. doi: https://doi.org/10.1017/s003329171600355x.

Mazmanian M., Orlikowski W. J. and Yates J. (2013). The autonomy paradox: the implications of mobile email devices for knowledge professionals, Organization Science 24: 1337-1357. doi: https://doi.org/10.1287/orsc.1120.0806.

Mogensen M. (2012). The organization(s) of well-being and productivity: (re)assembling work in the Danish Post. Ph.D.-serie 38.2012. 1 ed., Copenhagen: PhD School of Economics and Management, Copenhagen Business School.

Nickelsen N. C. (2008). Subjektivitet, materialitet og ledsmerter - om ANT-analysers bidrag til organisationspsykologi [Subjectivity, materiality and joint pain - on ANT-analyses contribution to organizational psychology], Psyke \& Logos 29: 238-260.

Nielsen M. B. and Knardahl S. (2020). The impact of office design on medically certified sickness absence, Scandinavian Journal of Work, Environment \& Health 46: 330-334. doi: https://doi.org/10.5271/sjweh.3859.

Nord C. and Högström E. (2017). Caring Architecture: Institutions and Relational Practices, Newcastle-upon-Tyne: Cambridge Scholars Publisher.

Orlikowski W. J. (2005). Material works: exploring the situated entanglement of technological performativity and human agency, Scandinavian Journal of Information Systems 17: 183-186.

Orlikowski W. J. (2007). Sociomaterial Practices: exploring technology at work, Organization Studies 28: 1435-1448. doi: https://doi.org/10.1177/0170840607081138.

Orlikowski W. J. (2010). The sociomateriality of organisational life: considering technology in management research, Cambridge Journal of Economics 34: 125-141. doi: https://doi. org/10.1093/cje/bep058.

Orlikowski W. J. and Scott S. V. (2008). Sociomateriality: challenging the separation of technology, work and organization, The Academy of Management Annals 2: 433-474. doi: https://doi.org/10.5465/19416520802211644. 
Parsons H. M. (1976). Work Environments. In: Altman I. and Wohlwill J. F. (eds) Human Behavior and Environment: Advances in Theory and Research, Boston, MA: Springer US, 163-209. doi: https://doi.org/10.1007/978-1-4684-2550-5 5.

Ravn I. (2008). Mening i arbejdslivet - definition og konceptualisering [Meaning in the work life - definition and conceptualization], Tidsskrift for Arbejdsliv 10: 59-75. doi: https:// doi.org/10.7146/tfa.v10i4.108735.

Rice A. K. (1963). The Enterprise and its Environment: A System Theory of Management Organization, London: Tavistock.

Roessler K. K. (2012). Healthy architecture! Can environments evoke emotional responses? Global Journal of Health Science 4: 83-89. doi: https://doi.org/10.5539/gjhs.v4n4p83.

Rugulies R., Aust B. and Madsen I. E. H. (2019). Occupational Determinants of Affective Disorders. In: Bültmann U. and Siegrist J. (eds) Handbook of Disability, Work and Health, Cham: Springer International Publishing, 1-28. doi: https://doi.org/10.1007/978-3-31975381-2 10-1.

Sasser M. and Sørensen O. H. (2016). Doing a good job - the effect of primary task quality on Well-Being and Job Satisfaction, Human Factors and Ergonomics in Manufacturing \& Service Industries 26: 323-336. doi: https://doi.org/10.1002/hfm.20648.

Sasser M. and Sørensen O. H. (2017). Kerneopgaven på dagsordenen [The primary task on the agenda]. Tidsskrift for Arbejdsliv 19: 78-93. doi: https://doi.org/10.7146/tfa.v19i1. 109079.

Semmer N., Jacobshagen N., Meier L., et al. (2007). Occupational Stress Research: the "Stress-as-Offense-to-Self" Perspective. In: Houdmont J. and McIntyre S. (eds) Occupational Health Psychology: European Perspectives on Research and Practice. Ismai publishers, 43-60.

Simonsen T. P. and Duff C. (2020). Healing architecture and psychiatric practice: (re)ordering work and space in an in-patient ward in Denmark, Sociology of Health \& Illness 42: 379-392. doi: https://doi.org/10.1111/1467-9566.13011.

Simonsen T. P. and Duff C. (2021). Mutual visibility and interaction: staff reactions to the 'healing architecture' of psychiatric inpatient wards in Denmark, BioSocieties 16: 249-269. doi: https://doi.org/10.1057/s41292-020-00195-4.

Spencer D. G. (1986). Employee voice and employee retention, The Academy of Management Journal 29: 488-502. doi: https://doi.org/10.5465/256220.

Sørensen O., Buch A., Christensen P., et al. (2007). Indflydelse i vidensarbejdet - kan man få for meget af det gode? [Influence in knowledge work - can one have too much of a good thing?] Tidsskrift for Arbejdsliv 9: 38-54. doi: https://doi.org/10.7146/tfa.v9i2. 108610.

Sørensen O. H. (2008). Arbejdets Kerne: Om at arbejde med Psykisk Arbejdsmiljø i Praksis [The core in work: working with mental working environment in practice], Copenhagen: Frydenlund.

Theorell T., Hammarstrom A., Aronsson G., et al. (2015). A systematic review including meta-analysis of work environment and depressive symptoms, BMC Public Health 15: 738. doi: https://doi.org/10.1186/s12889-015-1954-4.

Theorell T. and Karasek R. (1996). Current issues relating to psychosocial job strain and cardiovascular disease research, Journal of Occupational Health Psychology 1: 9-26. doi: https://doi.org/10.1037/1076-8998.1.1.9.

Thorsrud E., Emery F. and Trist E. (1964). Industrielt Demokrati: Representasjon på Styreplan i Bedriftene? Noen Norske og Utenlandske Erfaringer [Industrial Democracy. Representation on Managerial Level in Industry? Some Norwegian and International Lessons], Oslo: Universitetsforlaget.

Trist E. L. and Bamforth K. W. (1951). Some social and psychological consequences of the Longwall Method of coal-getting: an examination of the psychological situation and defences 
of a work group in relation to the social structure and technological content of the work system, Human Relations 4: 3-38. doi: https://doi.org/10.1177/001872675100400101.

Tufte P. (2013). Is there time enough? Temporal resources and service performance in the Danish home care sector, Nordic Journal of Working Life Studies 3: 97-112. doi: https:// doi.org/10.19154/njwls.v3i2.2552.

Tufte P. and Dahl H. M. (2016). Navigating the field of temporally framed care in the Danish home care sector, Sociology of Health \& Illness 38: 109-122. doi: https://doi.org/10.1111/ 1467-9566.12343.

Väänänen A. and Toivanen M. (2018). The challenge of tied autonomy for traditional work stress models, Work \& Stress 32: 1-5. doi: https://doi.org/10.1080/02678373.2017.141 5999.

Wilhelm J. J. and Battisto D. (2020). Architecture and Health: Guiding Principles for Practice, New York: Routledge. 